\title{
Microscopic aspects of lymphoid organs in the guinea pig (Cavia porcellus)
}

\author{
Fernanda Menezes de Oliveira e Silva * \\ Marcio Nogueira Rodrigues \\ Érika Toledo da Fonseca \\ André Luis Rezende Franciolli \\ Maria Angelica Miglino \\ Department of Surgery, School of Veterinary Medicine and Animal Science \\ University of São Paulo \\ Rua Prof. Dr. Orlando Marques de Paiva, 87, CEP 05508-000, São Paulo - SP, Brazil \\ * Corresponding author \\ fernanda.menezes@usp.br
}

Submetido em 06/03/2013

Aceito para publicação em 03/10/2013

\section{Resumo}

Aspectos microscópicos dos órgãos linfáticos do porquinho-da-índia (Cavia porcellus). A microscopia dos órgãos linfoides foi estudada em guinea pig em diferentes estágios de desenvolvimento - feto, filhote e adulto. O fígado é um órgão lobulado, revestido por um mesotélio, e consiste de sinusoides e placas de células em seu parênquima, denominadas hepatócitos. O timo é coberto por uma cápsula fina de tecido conjuntivo que se projeta como septos por todo o interior do órgão. O parênquima de cada lóbulo não está claramente separado em córtex e medula. Corpúsculos de Hassall são abundantes. Linfonodos estão organizados em córtex e medula. $\mathrm{O}$ córtex apresenta centros germinativos ou nódulos linfáticos, rodeados por tecido linfático difuso. O baço é dividido em polpa vermelha e branca. Trabéculas de tecido conjuntivo projetam-se para o interior do baço a partir da cápsula; contudo, estão presentes escassamente ao redor das polpas vermelhas e brancas. Centros germinativos estavam presentes na polpa branca, onde podem ser encontrados pequenos e grandes linfócitos e linfoblastos. Uma vez que o guinea pig é considerado um modelo importante para estudos morfológicos por sua proximidade com os seres humanos, este artigo levanta informações relevantes sobre os componentes estruturais do sistema linfático desses animais, proporcionando uma nova fonte de dados para outros campos do conhecimento.

Palavras-chave: Animais de laboratório; Guinea pig; Microscopia de luz; Sistema linfoide

\section{Abstract}

Microscopy of lymphoid organs was studied in the guinea pig at different developmental stages - fetus, pup, and adult. Liver is a lobed organ, coated with a mesothelium, and it consists of sinusoids and cell plates in its parenchyma, named hepatocytes. Thymus is covered by a thin capsule of connective tissue which is protruded as septa into the entire organ. The parenchyma of each lobule is not clearly separated into a cortex and medulla. Hassall's corpuscles are abundant. Lymph nodes are arranged into cortex and medulla. The cortex has germinal centers or lymphoid nodules, surrounded by diffuse lymphoid tissue. Spleen is divided into red and 
white pulp. Trabeculae of connective tissue are protruded into the spleen from the capsule; however, they are sparsely found around the red and white pulps. Germinal centers were found in the white pulp, where small and large lymphocytes and lymphoblasts can be found. Since the guinea pig is regarded as an important model for morphological studies due to its closeness to human beings, this article raises relevant information on the structural components of the lymphoid system in these animals, providing a new source of data to other knowledge fields.

Key words: Guinea pig; Laboratory animals; Light microscopy; Lymphoid system

\section{Introduction}

Animal models are often used for pre-clinical testing of drugs and vaccines. In order to choose the right species to use in a particular study, its immune system has to be closely related to that of humans. The similarities enable a better understanding of human diseases and they are useful for developing drugs used in human medicine (MERCHANT et al., 2011).

The main function of lymphoid organs is protecting the body against invading pathogens or antigens (bacteria, parasites, and viruses). The immune response occurs when the body detects the pathogen or antigen. Therefore, lymphoid cells, tissues, and organs have a wide distribution in the body. The major lymphoid organs are lymph nodes, tonsils, thymus, and spleen (EROSCHENKO, 2008).

A typical mammalian immune system is constantly changing throughout life. The immune system is established early in life by dispersing immune component cells from specific organs such as the thymus, which are maintained by means of the lymph nodes, bone marrow, spleen, and lymphoid cells in other tissues, such as the liver (PARHAM, 2009).

In rodents, the lymphoid anatomy and lymphatic drainage have been characterized for many different organs. Surprisingly, the morphology of the main lymphoid organs has not been clearly described. This knowledge is of great importance for allowing an accurate identification and characterization of immune responses to pathogens and for establishing new therapies and models (BARBIER et al., 2012).

Among laboratory animals, the guinea pig (Cavia porcellus), a rodent species belonging to the Caviidae family, is known as one of the most valuable models related to humans (KAISER et al., 2010), especially with regard to the human immune system and its response to diseases, since the immunological genes in this species are more similar to humans than those in mice (GUO et al., 2012).

This animal species is used in scientific experimentation since the $17^{\text {th }}$ century (PERCY; BARTHOLD, 2008) and it has been useful to provide a better understanding on the immune response at an early age (PILORZ et al., 2005). Its response to pathogens (BRODER et al., 1978), vaccines (JONES et al., 2003), infectious (PADILLA-CARLIN et al., 2008), and autoimmune-mediated diseases (GU et al., 2012) has been investigated.

Though the guinea pig has been an extremely useful animal model for investigating a wide variety of diseases, there is a lack of tools for undertaking a full-scale immunological analysis of this species (TAKIZAWA et al., 2006), especially with regard to the anatomical features of the main lymphoid organ, in order to analyze the changes that some pathologies can cause. This study aims to describe the microscopic features of lymphoid organs in the guinea pig, such as the spleen, thymus, lymph nodes, and liver, using individuals from different age groups.

\section{Material and Methods}

\section{Animals}

Female guinea pigs $(n=6)$ weighing from 150 to $400 \mathrm{~g}$ each, were obtained from a particular hatchery, and these individuals were free of pathogenic bacteria and parasites. They were individually housed in cages, being fed twice a day, and water was provided ad libitum. All procedures were performed in accordance with recommendations by the Research Ethical Committee of the School of Veterinary Medicine and Animal Science 
of University of São Paulo (FMVZ/USP), under the Protocol 1999/2010. The animals were divided into 3 groups according to their developmental stage: fetus $(\mathrm{n}=2)$, pup $(\mathrm{n}=2)$, and adults $(\mathrm{n}=2)$.

All animals were euthanized by anesthetic overdose with $50 \mathrm{mg} / \mathrm{kg}$ of ketamine (Ketamin-S ${ }^{\circledR}$, Cristália) and $2 \mathrm{mg} / \mathrm{kg}$ of xylazine hydrochloride (Calmiun ${ }^{\circledR}$, Union Agener); then, the necropsy was performed for collecting lymphoid organs, i.e. spleen, thymus, lymph nodes, and liver. Thymus collection was performed in all animals, being easier to recognize it in younger individuals. Lymph nodes were removed from the cervical (cranial and caudal) and abdominal (mesenteric and mesenteric root) regions.

Organs were collected after a postmortem interval ranging from 1 to $4 \mathrm{~h}$. Each organ was cut and fixed in 10 $\mathrm{mL}$ of $10 \%$ formalin for light and scanning microscopy.

\section{Light microscopy}

For light microscopy, samples were fixed in a $10 \%$ formalin solution for $24 \mathrm{~h}$. Then, they were washed in tap water and immersed in 70\% alcohol. Samples were dehydrated in a graded alcohol series (80-100\%) and embedded in paraplast. Transverse sections of $5 \mu \mathrm{m}$ were stained with Hematoxylin and eosin (H\&E). After staining, slides were examined and images were obtained using a ZEISS MC 80 DX microscope camera.

\section{Scanning microscopy}

For scanning electron microscopy, samples were fixed in a $10 \%$ formalin solution for $72 \mathrm{~h}$. Then, samples were washed in distilled water and post-fixed in a $1 \%$ osmium tetroxide solution for $2 \mathrm{~h}$ at $48^{\circ} \mathrm{C}$. They were dehydrated in a graded alcohol series, from $60 \%$ to P.A. Subsequently, samples were dried in liquid $\mathrm{CO}_{2}$ using a Balzers CPD 030 device, mounted on metal stubs, and, then, coated with gold in a sputter coater (Balzers SCD040). Samples were examined using a JEOL JSM-6100 scanning electron microscope.

\section{Results}

Results are presented in Figures 1 to 4 (light microscopy) and Figure 5 (scanning microscopy), separated according to developmental stages.

\section{Liver}

In the guinea pig, liver is a lobed organ; each lobe was coated by mesothelium, and there is a thin connective tissue layer beneath it. The hepatic tissue is divided into numerous lobules, consisting of sinusoids and cell plates in the parenchyma, named hepatocytes, radially organized around a central vein. A portal tract has one or more branches of a portal vein, hepatic artery, and lymphoid vessel. The bile ductile was observed close to each portal tract and its epithelium was simple cuboidal (Figures 1 and 5).

FIGURE 1: Guinea pig liver. In A (fetus): Transverse section through a lobule and central vein (arrowhead). 20x. In A1 (pup): Portal tract (highlighted): Hepatocytes (Hep); Portal vein, branch (PVb); Hepatic artery, central (HA). 20x. In A2 (adult): Hep; Portal Vein, transversal section (PVt); Lymphoid vessel (asterisk); and Bile ductile, (arrowhead). 40x.
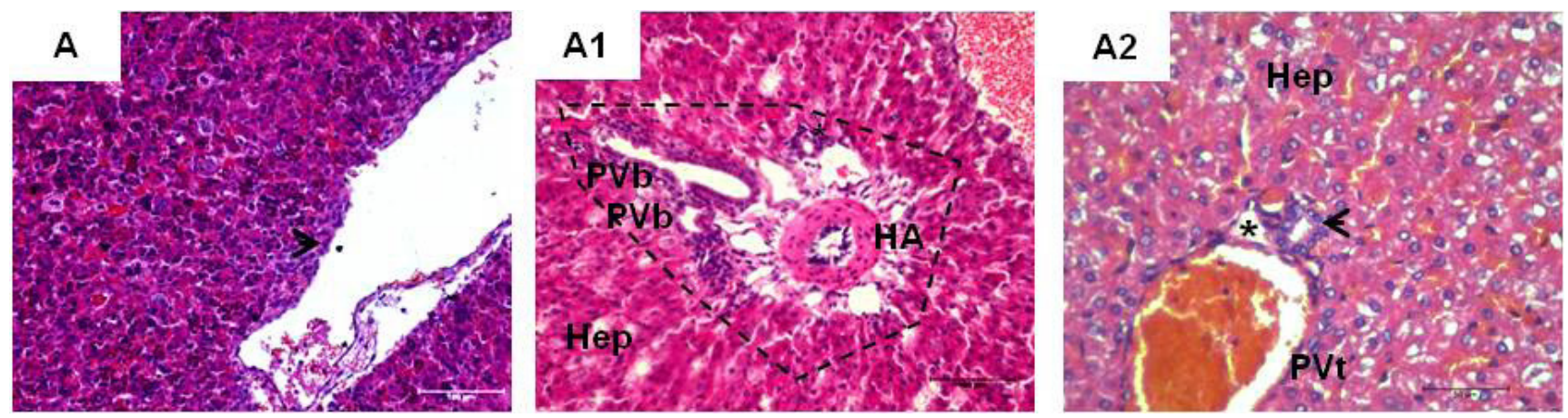


\section{Thymus}

The thymus was covered by a thin capsule of connective tissue which is protruded as septa into all organs. The parenchyma of each lobule was not clearly separated into a cortex and medulla. Densely packed thymic lymphocytes are observed in the cortex, as well as some basophilic granulocytes. Hassall's corpuscles, exclusively found in the thymus, are concentric whorls of acidophilic and flattened reticular cells, which may become swollen, keratinized, and centrally calcified (Figure 2).

\section{Lymph node}

A lymph node was organized into a cortex and medulla. The cortex had germinal centers with lymphoid nodules, surrounded by diffuse lymphoid tissue.
Extensions of lymphoid tissue, named medullary cords, were observed, as well as afferent lymphoid vessels and blood cells, such as lymphocytes (Figure 3).

\section{Spleen}

The spleen was divided into red and white pulp. The spleen had a capsule which is rich in smooth muscle and elastic fibers. Trabeculae of connective tissue were projected into the spleen from the capsule; however, they were also sparsely observed around the red and white pulps. Germinal centers are present in the white pulp, being responsible for the production of B cells and some lymphocytes. Red pulp is usually stained red in $\mathrm{H} \& \mathrm{E}$ preparations, due to its large number of erythrocytes, observed in its reticular meshwork and blood vessels (Figures 4 and 5).

FIGURE 2: Guinea pig thymus. In A (fetus): Cortex with several thymic lymphocytes (arrowhead) and some granulocytes (asterisk). Small trabecula (Tr) and Hassal's corpuscles (HaC). 40x. In A1 (pup): Medulla (M) and Cortex (C). 20x. In A2 (adult): separation between $\mathrm{M}$ and $\mathrm{C}$ is more clear, with the presence of trabeculae (arrowheads) and HaC. 20x.
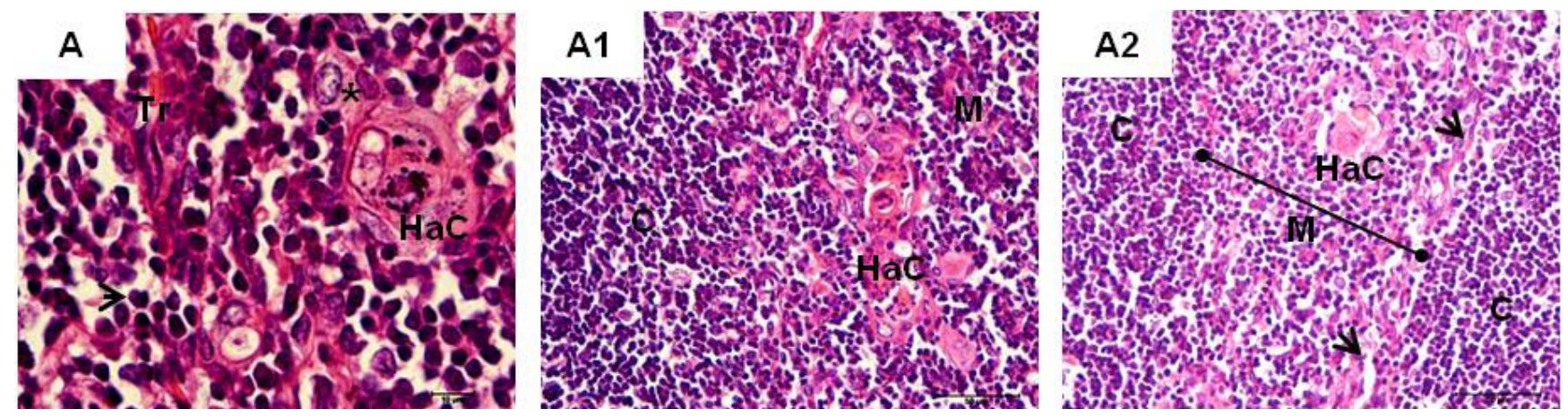

FIGURE 3: Guinea pig lymph node. In A (fetus): Cortex (C) and Medulla (M), with the presence of germinal center of lymphoid nodule in higher magnification. Efferent lymp hatic vessels indicated by arrowheads. 4x. In A1 (pup): Germinal center (highlighted); small trabeculae (arrowhead). 20x. In A2 (adult): Lymphocyte (arrowhead), Arteriole (Ae) and Reticular cells (asterisk). 40x.
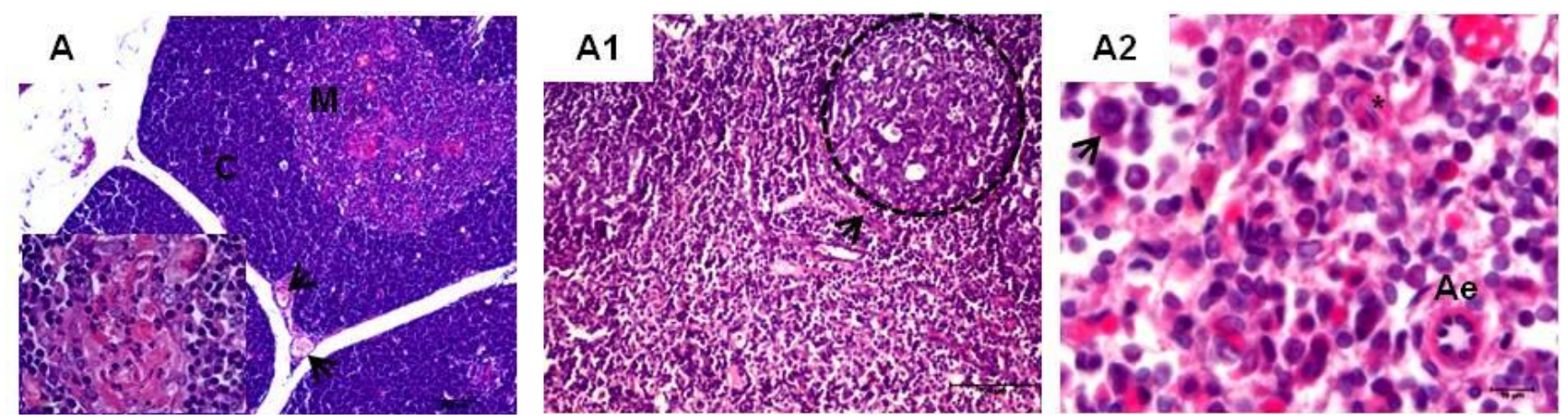
FIGURE 4: Guinea pig spleen. In A (fetus): Medulla with the presence of trabecula (Tr); Germinal center (highlighted) and arteriole (asterisk). 40x. In A1 (pup): White and red pulp (WP, RP, respectively) with the presence of a Trabecula (arrowhead). 40x. In A2 (adult): WP and RP with a trabeculae (arrowhead) in the center. 20x.
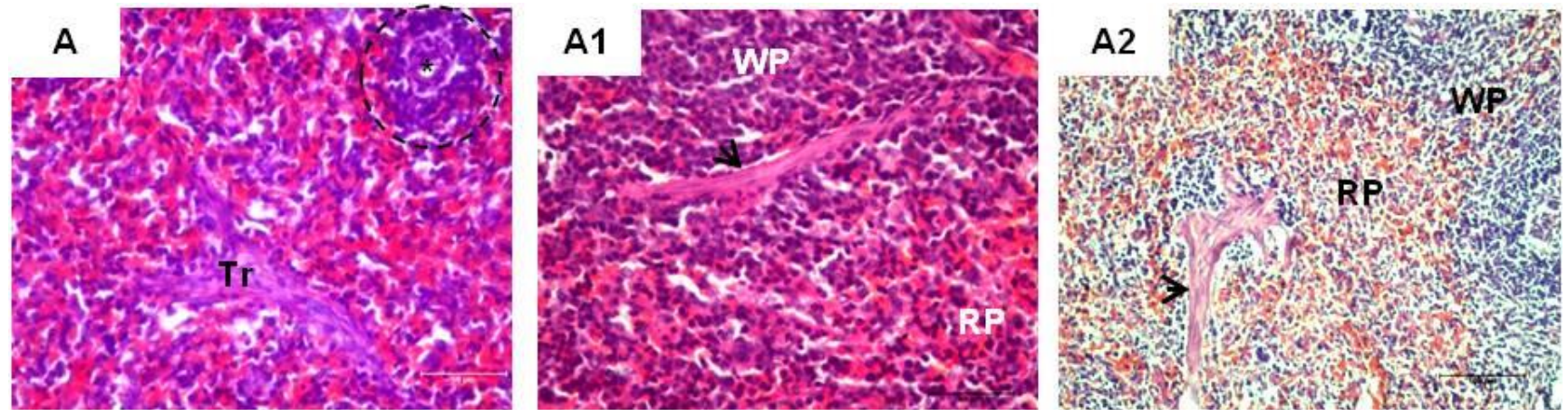

FIGURE 5: Scanning electron micrograph of guinea pig liver (A) and spleen (B). In A: Surface membrane (asterisk) and hepatocytes (arrowhead). In B: Surface membrane (asterisk), lymphocytes (Ly), capillaries (Ca), and trabeculae (arrowhead).
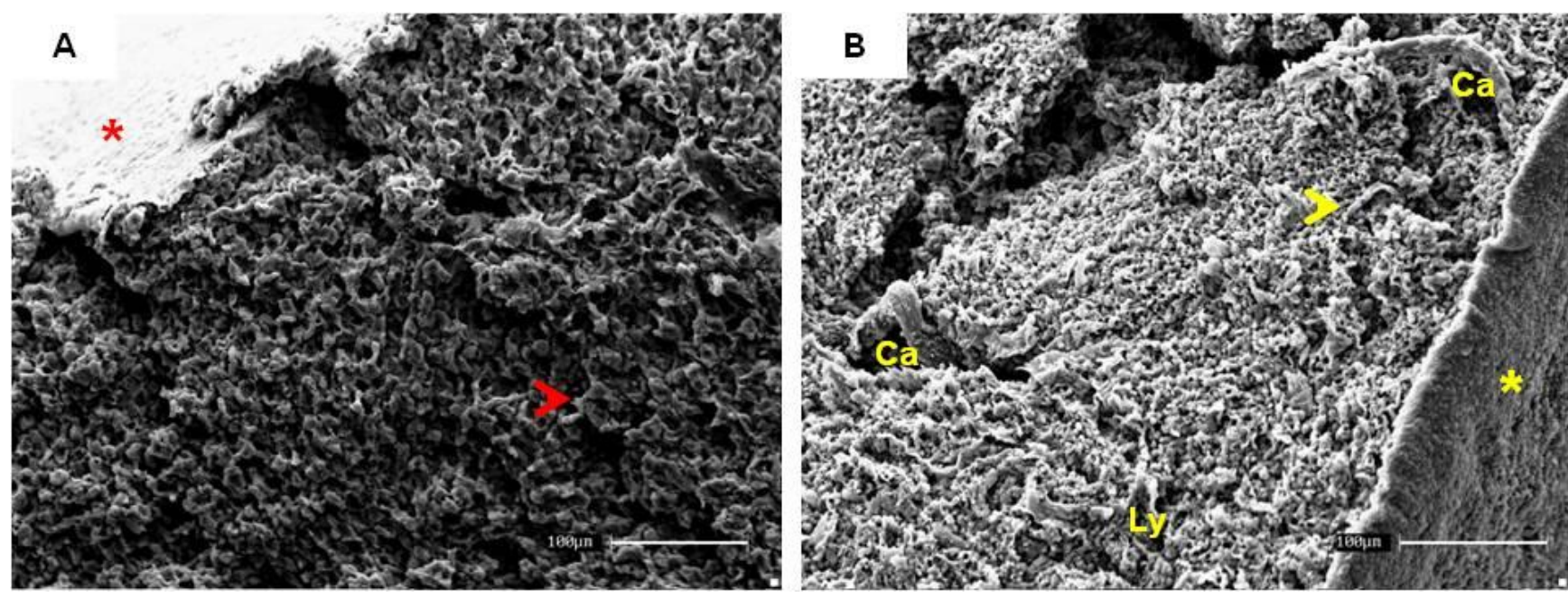

\section{Discussion}

The lymphoid system is perhaps the most poorly understood area of anatomy. Suami et al. (2011) reported that visualizing this system has been a difficult task for anatomic dissection studies. Anatomists have attempted to map the lymphatic system using various methods and materials, and there are few studies involving rodent lymphatic and lymphoid mapping. A popular method for studying this system in rodent species is injecting dye into the skin or abdomen of living rats and, then, euthanizing and dissecting them (JOB, 1915; TILNEY, 1971). In our studies, we have characterized, by light microscopy, components of the lymphoid system in the guinea pig.

In many species, including all rodent ones, the thymic tissue is replaced by adipocytes as the animal gets older. In guinea pigs, 10 to 12 years old individuals, or even older ones, have a predominance of adipose tissues. Recent phenotypic studies have explored changes in the rat thymus during the first year of life (QUAGLINO et al., 1998; CAPRI et al., 2000). Previous reports claimed that the evaluation of such changes is essential for a better understanding of the mechanisms and the biological significance of transformations induced by xenobiotic and, ultimately, complex mechanisms underlying thymic involution (QUAGLINO; RONCHETTI, 2001).

In rats, as well as in other rodent species, the thymus is mostly located in the thoracic region and partly in the cervical region, between the larynx, cranially, and 
the heart, caudally. In the mouse and rabbit, it is divided into 2 lobules (OSOBA, 1966; HEDRICH; BULLOCK, 2004) and nude rats are athymic (HUMMEL et al., 1975). However, the guinea pig thymus, unlike other mammals, remains a purely cervical organ (PARK, 1917) and it does not have an accessory lobe derived from the fourth pharyngeal pouch, so frequently observed in other species. This characteristic is still unclear, since Cooper and Schiller (1975) described the presence of accessory thymus in this species, something which was not observed in this study.

It is worth saying that the immune status of thymus is reflected on the histological appearance (PEARSE, 2006). The thymus of most mammals has its cortex formed by an extensive network of interconnecting spaces (EROSCHENKO, 2008). However, this feature was not observed in the guinea pig at any developmental stage. Immature lymphocytes were observed in the thymic parenchyma, probably migrating from hematopoietic tissues in the developing individual to undergo maturation and differentiation. When looking at thymic samples from adult individuals with considerable involution, all of them had at least a small number of lymphocytes within the thymus. The same finding was reported with regard to humans (STEINMANN, 1985), showing that the thymus does not become completely devoid of these cells.

Spleen is the largest secondary immune organ in the body, and it is responsible for initiating immune responses to blood-borne antigens and for filtering foreign material and old or damaged red blood cells (CESTA, 2006). Spleen in the guinea pig is divided into red and white pulp and it is covered by a capsule which is rich in smooth muscle and elastic fibers. The red pulp showed a large number of erythrocytes. This characteristic was described by many authors (COOPER; SCHILLER, 1975; HUMMEL et al., 1975; HEDRICH; BULLOCK, 2004; CESTA, 2006), who reported that the spleen is surrounded by a capsule (tunica serosa) from which several trabeculae, similar to those found in the guinea pig, are derived.

In rats and mice, the spleen is crucial for the production of lymphocytes and the degradation of old blood cells (SMITH; SCHENK, 2001). The red pulp is a blood filter which removes foreign material and damaged erythrocytes. In rodents, it is a site of hematopoiesis, particularly in fetal and neonatal animals (CESTA, 2006). A function of the white pulp is initiating immune responses to blood-borne antigens (KUPER et al., 2002; NOLTE et al., 2002; BALOGH et al., 2004).

The smallest lymph nodes may contain only a few lobules or even just one, while large lymph nodes may contain many lobules. These were described in lymph nodes as early as 1975 (KELLY, 1975), although some authors have described them as physiological compartments (BELISLE; SAINTE-MARIE, 1990). Lobules have been mentioned in more recent studies (GRETZ et al., 1997). Current best practice guidelines for examining a lymph node include a detailed observation of the cortex, paracortex, and medulla (HALEY et al., 2005). In our studies, we have observed that the cortex has germinal centers.

Lymphocytes and other leukocytes may be found in the medullary cords. Tilney (1971) reported that the lymph nodes contain a large number of lymphocytes, macrophages, and antigens presenting cells (APCs). Within the lymph nodes, APCs and primary lymphocytes are brought together to initiate primary immune responses (KALDJIAN et al., 2001). Lymph nodes are, essentially, data marketplaces where lymphocytes come to display information gathered about antigens they have found in the field (WILLARD-MACK, 2006).

Liver is a heterogeneous tissue whose functional unit in the lobule has stumped morphologists for over 300 years (see MACSWEEN et al., 2002). It is amazing that, no matter the angle at which a liver is sectioned, it basically has the same histological appearance, i.e., multiple units with a hepatic venule (also known as central vein) centrally surrounded by about 4-6 portal areas. In the guinea pig, liver is a lobed organ and it consists of sinusoids and cell plate in the parenchyma, named hepatocytes, radially organized around a central vein. We observed that the portal tract has one or more branches of a portal vein, hepatic artery, and lymphoid vessel. The bile ductile was observed close to each portal tract and its epithelium was simple cuboidal.

To effectively and quickly fight against potentially toxic agents without using harmful immune responses, 
the liver relies on its strong immune system. This involves enriching immune cells and removing waste molecules, as well as an immunologic elimination of microorganisms through liver endothelial cells and Kupffer cells. In addition, liver also plays an important role by controlling systemic innate immunity by means of the biosynthesis of numerous soluble pathogenrecognition receptors and complementary components (GAO; JEONG; TIAN, 2008).

It is extremely important knowing the lymphoid system morphology, since its components may be affected by a large number of pathologies, in addition to the fact that this system works as a sentinel to detect many pathologies from other systems. A large number of changes has been reported in the lymphoid and hematopoietic system in mice, it has been argued that these animals are an excellent model for studying morphological pathologies (FRITH et al., 1996).

The guinea pig constitutes an important model for this kind of study, as its morphological characteristics are similar to those of humans; this species may be useful for establishing study models, including for cell therapy. Thus, this article raises relevant information on the structural components of the lymphoid system in these species, providing a new source of data to other knowledge fields.

\section{Acknowledgments}

The authors thank Mr. Ronaldo Agostinho da Silva and Mrs. Rose Eli Grassi Rici, for their technical assistance during microscopy analysis. All authors declare that there is no conflict of interest.

\section{References}

BALOGH, P.; HORVATH, G.; SZAKAL, A. K. Immunoarchitecture of distinct reticular fibroblastic domains in the white pulp of mouse spleen. Journal of Histochemistry \& Cytochemistry, Baltimore, v. 52, p. 1287-1298, 2004.

BARBIER, L.; TAY, S. S.; MCGUFFOG, C.; TRICCAS, J. A.; MCCAUGHAN, G. W.; BOWEN, D. G.; BERTOLINO, P. Two lymph nodes draining the mouse liver are the preferential site of DC migration and $\mathrm{T}$ cell activation. Journal of Hepatology, Amsterdam, v. 57, n. 2, p. 352-358, 2012.
BELISLE, C.; SAINTE-MARIE, G. Blood vascular network of the rat lymph node: tridimensional studies by light and scanning electron microscopy. The American Journal of Anatomy, New York, v. 189, n. 2, p. 111-126, 1990.

BRODER, I.; ROGERS, S.; CHAMBERLAIN, D. W.; MILNE, E. N. Model of allergic bronchoconstriction in the guinea pig: I. Characteristics of the system. Clinical Immunology and Immunopathology, New York, v. 9, n. 1, p. 1-15, 1978.

CAPRI, M.; QUAGLINO, D.; VERZELLA, G.; MONTI, D.; BONAFÈ, M.; COSSARIZZA, A.; TROIANO, L.; ZECCA, L.; PASQUALI-RONCHETTI, I.; FRANCESCHI, C. A cytofluorimetric study of $\mathrm{T}$ lymphocyte subsets in rat lymphoid tissues (thymus, lymph nodes) and peripheral blood: A continuous remodelling during the first year of life. Experimental Gerontology, Boulder, v. 35, p. 613-625, 2000.

CESTA, M. F. Normal structure, function, and histology of the spleen. Toxicologic Pathology, Thousand Oaks, v. 34, p. 455-465, 2006.

COOPER, G.; SCHILLER, A. L. Lymphatic system. In: COOPER, G.; SCHILLER, A. L. (Ed.). Anatomy of the guinea pig. Cambridge: Harvard University Press, 1975. p. 213-221.

EROSCHENKO, V. P. Di Fiore's atlas of histology with functional correlations. 11 ed. Philadelphia: Lippincott Williams \& Wilkins. 2008. 552 p.

FRITH, C. H.; WARD, J. M.; BROWN, R. H.; TYLER, R. D.; CHANDRA, M.; STROMBERG, P. C. Proliferative lesions of the hematopoietic and lymphatic systems in rats. In: FRITH, C. H.; WARD, J. M.; BROWN, R. H.; TYLER, R. D.; CHANDRA, M.; STROMBERG, P. C. ( Ed.). Guides for toxicologic Pathology. Washington: STP/ARP/AFIP, 1996. p. 1-20.

GAO, B.; JEONG, W.; TIAN, Z. Liver: an organ with predominant innate immunity. Hepatology, Baltimore, v. 47, n. 2, p. 729-736, 2008.

GRETZ, J. E.; ANDERSON, A. O.; SHAW, S. Cords, channels, corridors and conduits: critical architectural elements facilitating cell interactions in the lymph node cortex. Immunological Reviews, Copenhagen, v. 156, p. 11-24, 1997.

GU, Y.; CHEN, Z. W.; SIEGEL, A.; KOSHY, R.; RAMIREZ, C.; RAABE, T. D.; DEVRIES, G. H.; ILYAS, A. A. Analysis of humoral immune responses to LM1 ganglioside in guinea pigs. Journal of Neuroimmunology, Amsterdam, v. 246, n. 1-2, p. 58-64, 2012.

GUO, Y.; BAO, Y.; MENG, Q.; HU, X.; MENG, Q.; REN, L.; LI, $\mathrm{N}$.; ZHAO, Y. Immunoglobulin genomics in the guinea pig (Cavia porcellus). PLoS One, San Francisco, v. 7, n. 6, e39298, 2012.

HALEY, P.; PERRY, R.; ENNULAT, D.; FRAME, S.; JOHNSON, C.; LAPOINTE, J. M.; NYSKA, A.; SNYDER, P.; WALKER, D.; WALTER, G. STP position paper: best practice guideline for the routine pathology evaluation of the immune system. Toxicologic Pathology, Thousand Oaks, v. 33, n. 3, p. 404-407, 2005.

HEDRICH, H. J.; BULLOCK, G. The laboratory mouse. London: Elsevier Academic Press, 2004. 600 p.

HUMMEL, K. P.; RICHARDSON, F. L.; FEKETE, E. Anatomy. In: GREEN, E. L. (Ed). Biology of the laboratory mouse. New York: Dover Publications, 1975. p. 247-307.

JOB, T. T. The adult anatomy of the lymphatic system in the common rat (epims norveguicus). The Anatomical Record, Chichester, v. 9, p. 447-455, 1915. 
JONES, S. M.; GRIFFIN, K. F.; HODGSON, I.; WILLIAMSON, E. D. Protective efficacy of a fully recombinant plague vaccine in the guinea pig. Vaccine, Amsterdam, v. 21, n. 25-26, p. 3912-3918, 2003.

KAISER, S.; KRÜGER, C.; SACHSER, N. The guinea pig. In: HUBRECHT, R.; KIRKWOOD, J. (Ed.). The UFAW Handbook on the Care and Management of Laboratory and Other Research Animals, Eighth Edition. Oxford: Wiley-Blackwell, 2010. p. 380-398.

KALDJIAN, E. P.; GRETZ, J. E.; ANDERSON, A. O.; SHI, Y.; SHAW, S. Spatial and molecular organization of lymph node $\mathrm{T}$ cell cortex: a labyrinthine cavity bounded by an epithelium-like monolayer of fibroblastic reticular cells anchored to basement membrane-like extracellular matrix. International Immunology, Oxford, v. 13, p. 1243-1253, 2001.

KELLY, R. H. Functional anatomy of lymph nodes. I. The paracortical cords. International Archives of Allergy and Applied Immunology, New York, v. 48, p. 836-849, 1975.

KUPER D. F.; DE HEER, E.; VAN LOVEREN, H. VOS J. G. Immune system. In: HASCHEK, W. M.; ROUSSEAUX, C. G.; WALLIG, M. A. (Ed.). Handbook of Toxicologic Pathology. San Diego: Academic Press, 2002. p. 585-646.

MACSWEEN, R. N. M.; DESMET, V. J.; ROSKAMS, T.; SCOTHORNE, R. J. Developmental anatomy and normal structure. In: BURT, A. D.; PORTMANN, B. C.; FERRELL, L. D. (Ed.). MacSween's pathology of the liver. New York: Churchill Livingstone, 2002. p. 1-66.

MERCHANT,H.A.;MCCONNELL,E.L.;LIU,F.; RAMASWAMY, C.; KULKARNI, R. P.; BASIT, A. W.; MURDAN, S. Assessment of gastrointestinal $\mathrm{pH}$, fluid and lymphoid tissue in the guinea pig, rabbit and pig, and implications for their use in drug development. European Journal of Pharmaceutical Science, Amsterdam, v. 42, n. 1-2, p. 3-10, 2011.

NOLTE, M. A.; HAMANN, A.; KRAAL, G.; MEBIUS, R. E. The strict regulation of lymphocyte migration to splenic white pulp does not involve common homing receptors. Immunology, Oxford, v. 106, n. 3, p. 299-307, 2002.

OSOBA, D. The functions of the thymus. Canadian Medical Association Journal, Toronto, v. 94, n. 10, p. 488-497, 1966.

PADILLA-CARLIN, D. J.; MCMURRAY, D. N.; HICKEY, A. J. The guinea pig as a model of infectious diseases. Comparative Medicine, Memphis, v. 58, n. 4, p. 324-340, 2008.

PARHAM, P. The Immune System. New York: Garland Science, 2009. $608 \mathrm{p}$.
PARK, E. A. Extirpation of the thymus in the guinea pig. The Journal of Experimental Medicine, New York, v. 25, n. 1, p. 129 152, 1917.

PEARSE, G. Histopathology of the thymus. Toxicologic Pathology, Thousand Oaks, v. 34, n. 5, p. 515-547, 2006.

PERCY, D. H.; BARTHOLD, S. W. Guinea pig. In: PERCY, D. H.; BARTHOLD, S. W. (Ed.). Pathology of laboratory rodents and rabbits. Iowa: Blackwell Publishing Professional, 2008. p. 217-251.

PILORZ, V.; JÄCKEL, M.; KNUDSEN, K.; TRILLMICH, F. The cost of a specific immune response in young guinea pigs. Physiology \& Behavior, Oxford, v. 85, n. 2, p. 205-211, 2005.

QUAGLINO, D. JR.; CAPRI, M.; BERGAMINI, G.; EUCLIDI, E.; ZECCA, L.; FRANCESCHI, C.; PASQUALI-RONCHETTI, I. Age-dependent remodeling of rat thymus. Morphological and cytofluorimetric analysis from birth up to one year of age. European Journal of Cell Biology, Stuttgart, v. 76, n. 2, p. 156-166, 1998.

QUAGLINO, D.; RONCHETTI, I. P. Cell death in the rat thymus: a minireview. Apoptosis, London, v. 6, n. 5, p. 389-401, 2001.

SMITH, D. G.; SCHENK, M. P. A dissection guide \& atlas of the rat. Colorado: Morton Publishing Company, 2001. 120 p.

STEINMANN, G. G.; KLAUS, P.; MÜLLER-HERMELINK, $\mathrm{H}$. K. The involution of the ageing human thymic epithelium is independent of puberty - a morphometric study. Scandinavian Journal of Immunology, Oxford, v. 22, p. 563-575, 1985.

SUAMI, H.; CHANG, D. W.; MATSUMOTO, K.; KIMATA, Y. Demonstrating the lymphatic system in rats with microinjection. The Anatomical Record, Chichester, v. 294, n. 9, p. 1566-1573, 2011.

TAKIZAWA, M.; CHIBA, J.; HAGA, S.; ASANO, T.; YAMAZAKI, T.; YAMAMOTO, N.; HONDA M. Novel twoparameter flow cytometry (MIL4/SSC followed by MIL4/CT7) allows for identification of five fractions of guinea pig leukocytes in peripheral blood and lymphoid organs. Journal of Immunological Methods, Amsterdam, v. 311, n. 1-2, p. 47-56, 2006.

TILNEY, N. L. Patterns of lymphatic drainage in the adult laboratory rat. Journal of Anatomy, London, v. 109, n. 3, p. 369-383, 1971.

WILLARD-MACK, C. L. Normal structure, function, and histology of lymph nodes. Toxicologic Pathology, Thousand Oaks, v. 34, n. 5, p. 409-424, 2006. 